\title{
LUMINESCENCE DATING OF FLUVIAL DEPOSITS FROM THE WESER VALLEY, GERMANY
}

\author{
JULIA ROSKOSCH ${ }^{1,2}$, SUMIKO TSUKAMOTO ${ }^{2}$, MANFRED FRECHEN ${ }^{2}$ \\ ${ }^{I}$ Institut für Geologie, Leibniz Universität Hannover, Callinstraße 30, D-30167 Hannover, Germany \\ ${ }^{2}$ Leibniz Institute for Applied Geophysics (LIAG), Stilleweg 2, D-30655 Hannover, Germany
}

Received 25 October 2014 Accepted 25 May 2015

\begin{abstract}
Luminescence dating was applied on coarse-grained monomineralic potassium-rich feldspar and polymineralic fine-grained minerals of five samples derived from fluvial deposits of the River Weser in northwestern Germany. We used a pulsed infrared stimulated luminescence (IRSL) single aliquot regenerative (SAR) dose protocol with an IR stimulation at $50^{\circ} \mathrm{C}$ for $400 \mathrm{~s}(50 \mu \mathrm{s}$ on-time and $200 \mu$ s off-time). In order to obtain a stable luminescence signal, only off-time IRSL signal was recorded. Performance tests gave solid results. Anomalous fading was intended to be reduced by using the pulsed IRSL signal measured at $50^{\circ} \mathrm{C}\left(\mathrm{IR}_{50}\right)$, but fading correction was in most cases necessary due to moderate fading rates. Fading uncorrected and corrected pulsed $\mathrm{IR}_{50}$ ages revealed two major fluvial aggradation phases during the Late Pleistocene, namely during marine isotope stage (MIS) $5 \mathrm{~d}$ $(100 \pm 5 \mathrm{ka})$ and from late MIS $5 \mathrm{~b}$ to MIS $4(77 \pm 6 \mathrm{ka}$ to $68 \pm 5 \mathrm{ka})$. The obtained luminescence ages are consistent with previous ${ }^{230} \mathrm{Th} / \mathrm{U}$ dating results from underlying interglacial deposits of the same pit, which are correlated with MIS 7c to early MIS 6.
\end{abstract}

Keywords: pulsed infrared stimulated luminescence, fluvial deposits, independent age control, Late Pleistocene, Weser valley, northern Germany.

\section{INTRODUCTION}

Optically stimulated luminescence (OSL) dating was applied to fluvial deposits in order to give insights into the timing of fluvial aggradation and degradation (e.g. Wallinga, 2002; Busschers et al., 2008; Cordier et al., 2010; Lauer et al., 2010). The major difficulty in dating sediments by means of luminescence is mainly caused by the occurrence of insufficient bleaching of the luminescence signal, which is considered a great challenge for especially fluvial deposits (e.g. Murray et al., 1995; Gemmell, 1997; Olley et al., 1999; Stokes et al., 2001). In a fluvial environment, insufficient bleaching can be

Corresponding author: J. Roskosch

e-mail: j.roskosch@gmx.net caused by different environmental conditions, such as water depth, transport distance, and the mode of transport. In the water column, sunlight is being attenuated and therefore generally hampers the probability for the transported minerals to be sufficiently bleached. Furthermore, rapid erosion and transport due to storm, highdischarge and flooding events may also limit the time needed for resetting the luminescence signal (cf. Wallinga, 2002; Jain et al., 2004; Rittenour, 2008). However, luminescence dating of fluvial deposits has been successfully applied in many case studies (Lewis et al., 2001; Wallinga et al., 2001; Rittenour et al., 2005; Briant et al., 2006; Choi et al., 2007; Busschers et al., 2008; Frechen et al., 2008, 2010; Krbetschek et al., 2008; Lauer et al., 2010, 2011). Lauer et al. (2011) compared the quartz and feldspar luminescence ages from fluvial sand samples from the River Rhine intercalated with the Laacher See tephra (12.9 ka). Both quartz and feldspar 
ages agreed perfectly with the independent tephra age, suggesting that insufficient bleaching, if any, might not be a problem for Pleistocene samples.

In order to check if the problem related to insufficient bleaching exists, one can perform measurements of multiple luminescence signals with different bleachabilities and compare the obtained results with each other. Such comparison is normally done using quartz and feldspar signals (e.g. Murray et al., 2012). The use of quartz minerals for luminescence measurements is often restricted to younger deposits ( $\leq 70 \mathrm{ka}$; e.g. Fuchs and Lang, 2001; Lewis et al., 2001; Wallinga, 2002; Briant et al., 2006; Busschers et al., 2008) due to the lower saturation level of quartz (about 100-200 Gy). The quartz luminescence signal is much more light-sensitive, thus faster to bleach than the feldspar luminescence signal, but feldspar minerals allow for dating comparably older (fluvial) sediments (e.g. Krbetschek et al., 2008; Lauer et al., 2011) due to the higher saturation limit of the luminescence signal. Yet, feldspar minerals may suffer from a certain signal loss over time, referred to as anomalous fading (Wintle, 1973; Aitken, 1985; Spooner, 1994). When the quartz OSL signal cannot be used, equivalent doses or ages obtained from the infrared stimulated luminescence (IRSL) signal measured at low temperatures and the postIR IRSL signal has also been used for comparison to evaluate the bleaching degree of a sample (Buylaert et al., 2013).

However, in order to identify the limits of different dating methods, including their uncertainties, and to calibrate the chronological framework, independent age control can be substantially helpful. Independent age control can be provided e.g. by additional radiocarbon $\left({ }^{14} \mathrm{C}\right)$ dating (e.g., Thomas et al., 2006; Frechen et al., 2008; Murray et al., 2012), electron spin resonance dating (ESR; e.g., Molodkov, 2012; Zhao et al., 2012), amino acid racemization (AAR; e.g., Novothny et al., 2009) or uranium-thorium $\left({ }^{230} \mathrm{U} / \mathrm{Th}\right.$ ) dating (this study) of (i) the sediment itself or of (ii) the under- and/or overlying deposits, depending on the availability of appropriate dating material (e.g. organic matter in case of ${ }^{14} \mathrm{C}$ dating). Given the fact that results of all applied dating methods are consistent with each other, the accuracy and reliability of the performed dating technique(s) can be proven.

In this study, we present new feldspar luminescence ages of fluvial deposits in northwestern Germany, which are supported by independent age control based on ${ }^{230} \mathrm{U} / \mathrm{Th}$ dating of underlying interglacial deposits. The obtained luminescence ages are of great importance as they shed new light on the previously established Middle to Late Pleistocene depositional model of the studied area.

\section{STUDY AREA AND PREVIOUS RESEARCH}

\section{Study area}

The study area is located in the southern Weser valley in northwestern Germany (Fig. 1A) and is characterised by up to $530 \mathrm{~m}$ high mountain ridges of the Central German Uplands (Fig. 1B). Here, the folded Variscan basement is unconformably overlain by Lower Permian red beds ('Rotliegend'), Upper Permian marine evaporites and carbonates ('Zechstein'), Lower Triassic sandstones ('Buntsandstein') and Middle Triassic shallow marine sediments ('Muschelkalk') (Lepper and Mengeling, 1990; Lepper, 1991). From the late Cretaceous to the Neogene, these sediments experienced uplift, which led to a subsequent incision of the River Weser that formed its isoclinal valley between the Buntsandstein anticlinal at its east and the steep cuestas of the outcropping Lower Muschelkalk at its west during the subsequent Neogene to Late Pleistocene (Grupe, 1912, 1929; Lepper, 1991).

The Nachtigall pit is located at the western flank of the Buntsandstein anticlinal about $5 \mathrm{~km}$ southwest of Holzminden (Fig. 1B). The lowermost part of the sedimentary record, probably comprising Middle Pleistocene (Saalian) fluvial deposits of the River Weser (e.g. Rohde, 1989; Rohde et al., 2012), is not exposed in the studied Nachtigall pit but is assumed to occur at an altitude range from about 70-80 $\mathrm{m}$ a.s.l. (Rohde et al., 2012). Generally, the term "terrace" is geomorphologically defined as and associated with those deposits preserved above the present floodplain. In this paper, the terms "Older and Younger Middle Terraces and "Lower Terraces" are used on a geochronological basis, referring to those fluvial

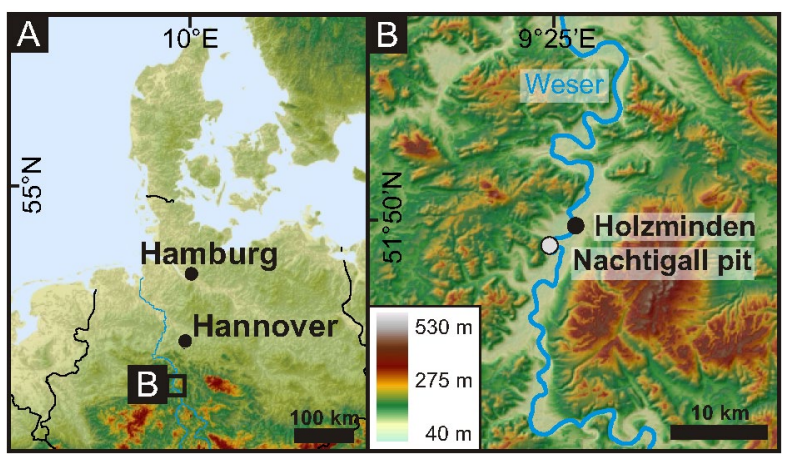

Fig. 1. (A) Map of northern Central Europe focusing on northern Germany. The black box marks the study area. The hill-shaded relief model is based on SRTM data. (B) Close-up view of the study area of Weser valley with location of the Nachtigall pit. The hill-shaded relief model (DEM5) is based on data from the Landesamt für Geoinformation und Landesvermessung Niedersachsen (LGLN). 
deposits that are considered to have been accumulated during the Middle and Late Pleistocene. Older and Younger Middle Terrace deposits are both considered to have been accumulated after the retreat of the Elsterian glaciation and prior to the advance of the Saalian Drenthe ice sheets (Middle Pleistocene), namely during the early Saalian (Older Middle Terrace) and during the late Saalian (Younger Middle Terrace). Deposition of the Lower Terrace is linked to the Weichselian glaciation (Late Pleistocene) (Rohde et al., 2012).

The unexposed fluvial deposits are referred to as Older Middle Terrace deposits and are overlain by $13-25 \mathrm{~m}$ thick fine-grained interglacial limnic and fen peat of the so-called Nachtigall-Complex. The Nachtigall-Complex ranges over an altitude of about $80-96 \mathrm{~m}$ a.s.l. (Rohde et al., 2012; this study). The interglacial deposits are unconformably overlain by $8 \mathrm{~m}$ thick coarse-grained fluvial sediments, occurring over an altitude range of 96-104 m a.s.l., deposited by a braided river system (Winsemann et al., 2015) (Figs. 2A and 2B). These fluvial deposits are referred to as Younger Middle Terrace deposits (e.g. Rohde, 1989; Kleinmann et al., 2011; Waas et al., 2011; Rohde et al., 2012).

In the western part of the pit, the lowermost $5 \mathrm{~m}$ of the braided river deposits (96-101 m a.s.1.) consist of gravel sheet deposits, which are overlain by up to $1 \mathrm{~m}$ thick fine-grained overbank deposits, consisting mainly of ripple cross-laminated and planar-parallel laminated silt and silty sand. These overbank deposits, which are intercalated with up to $0.4 \mathrm{~m}$ thick gravel sheet deposits, are truncated and overlain by about $2 \mathrm{~m}$ thick gravel sheet deposits (Winsemann et al., 2015) (Fig. 2A). The fluvial deposits in the western and eastern parts of the Nachtigall pit are separated by a major (erosional) bounding surface, characterised by a vertical erosion of about $9 \mathrm{~m}$ (Fig. 2B).
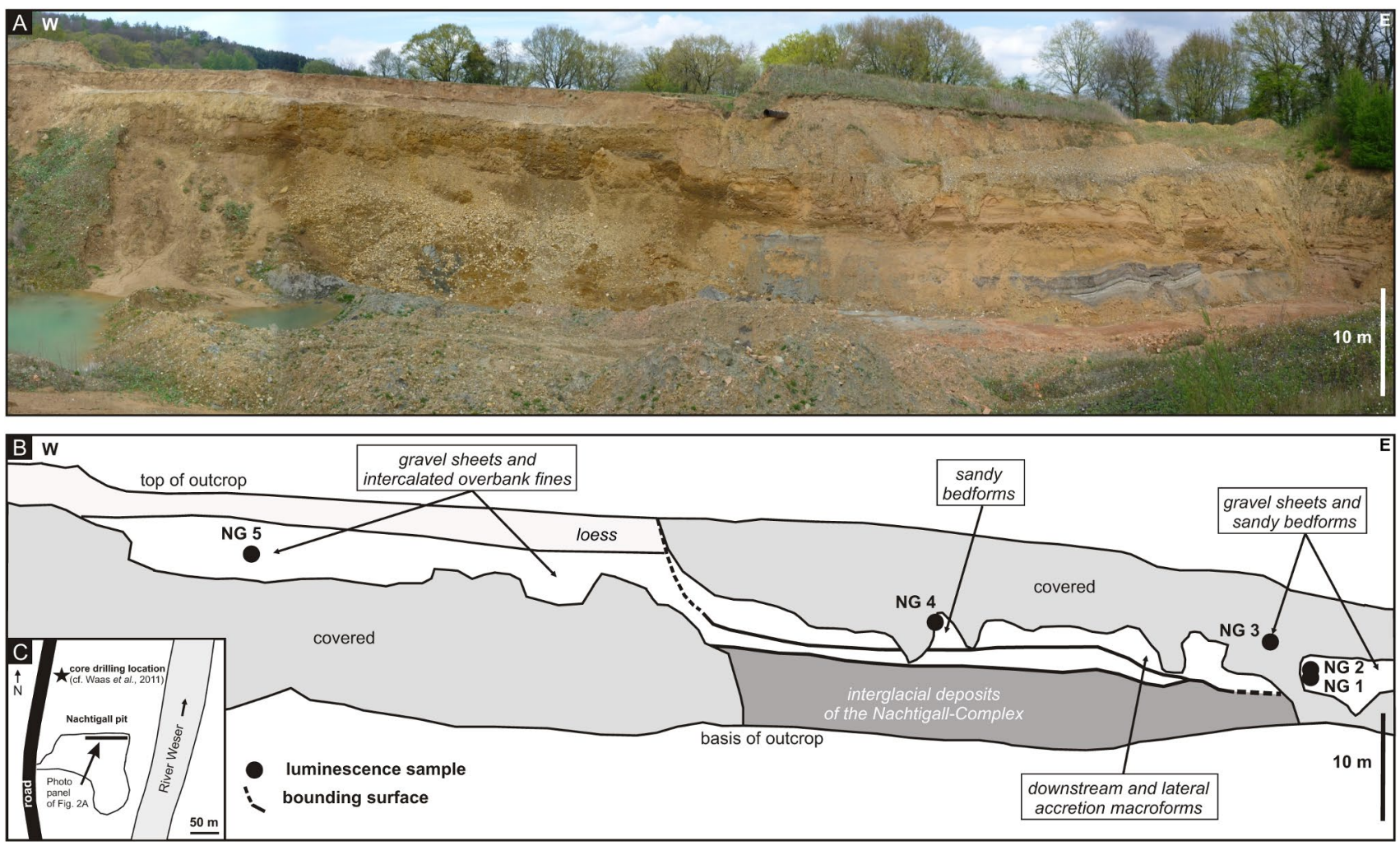

Fig. 2. (A) Photo panel and (B) line drawing of the Nachtigall pit. Covered and unexposed deposits are grey, fine-grained interglacial limnic and fen peat deposits of the Nachtigall-Complex occur over an altitude range of about 80-96 m a.s.l. (dark grey) and are overlain by braided river deposits, occurring over an altitude range of about 90-104 $\mathrm{m}$ a.s.l. (white), and by loess (light grey). Two major erosional bounding surfaces are indicated (black lines). The lowermost bounding surface separates the interglacial from the overlying fluvial deposits. The uppermost bounding surface of about $9 \mathrm{~m}$ separates the western from the eastern fluvial deposits. In the west, braided river deposits (96-104 $\mathrm{m}$ a.s.l.) are characterised by gravel sheet deposits, overlain by fine-grained overbank deposits (sample NG5), which are again overlain by gravel sheet deposits. In the east, braided river deposits (about 90-103 $\mathrm{m}$ a.s.l.) are characterised by channel belt deposits, lateral and downstream macroforms, and sandy bedforms (samples NG1 to NG4) which are truncated and overlain by gravel sheet deposits (Winsemann et al., in review). Luminescence samples are indicated (black circles). Note that dimensions may be distorted due to panorama view. (C) Schematic outline of the Nachtigall pit. Locations of the photo panel of Fig. $2 A$ and of the core drilling (black star) referred to in Waas et al. (2011) and Kleinmann et al. (2011) are marked. The 230U/Th samples by Waas et al. (2011) were taken from the core about 175 m northwest from sample NG1. 
The fluvial sediments in the eastern part of the pit are at least $15 \mathrm{~m}$ thick and consist of channel belt and overbank deposits of a gravelly to sandy braided river system (Winsemann et al., 2015). Exposed fluvial deposits occur over an altitude range of about 90-103 m a.s.l. (Figs. 2A and $2 \mathrm{~B}$ ). Here, the lowermost part is characterised by about $2 \mathrm{~m}$ thick channel-fill deposits, passing upwards into lateral and downstream accretion macroforms as well as sandy bedforms, comprising planar-parallel stratified, planar or trough cross-stratified or ripple cross-laminated medium- to fine-grained sand. These deposits are truncated and overlain by about $4 \mathrm{~m}$ thick gravel sheets (Winsemann et al., 2015) (Fig. 2A). Locally, deposits are overlain by fine-grained floodplain deposits and draped by loess. The floodplain area of River Weser is expected to comprise Late Pleistocene (Weichselian) fluvial deposits (cf. Rohde et al., 2012). For further detailed information on the sedimentology of the Nachtigall deposits and the large-scale depositional architecture, which is being reconstructed from the outcrop section and digital elevation models, see Winsemann et al. (2015).

\section{Previous research}

Reconstruction of the fluvial terrace architecture of the River Weser is largely based on lithostratigraphy and morphology (Rohde, 1983, 1989, 1994). Up to 11 terrace levels were mapped, recording about $170 \mathrm{~m}$ of fluvial incision during the Pleistocene (Fromm, 1989; Rohde 1989, 1994).

The Nachtigall pit, which has long been exploited for brick production, must be considered as a key section because its interglacial sediments were intensely analysed especially by means of palynology in order to correlate the deposits with other interglacial successions in Germany and France (e.g. Kleinmann et al., 2011). Studies dealing with the deposits of the Nachtigall pit go back to the $19^{\text {th }}$ century and focused on the interglacial sediments (e.g. Dechen, 1884; Carthaus, 1886; Koken, 1901). The interglacial deposits exposed were allocated either to the Holsteinian (based on pollen analysis; Grupe, 1929) or to the Eemian (based on their stratigraphic position related to the Middle Terrace deposits; Siegert, 1912, 1921; Soergel, 1927, 1939). Much later, Mangelsdorf (1981) performed detailed palynological analysis on the interglacial deposits and proposed a late Cromerian age (Bilshausen/Rhume interglacial). Later pollen analysis of the interglacial sediments of the Nachtigall pit did not support such a late Cromerian age but tentatively pointed to a Saalian deposition (Lepper, 1998). Recently, ${ }^{230} \mathrm{U} / \mathrm{Th}$ dating and palynological studies on the interglacial limnic sediments support this finding and refer to a deposition during MIS 7c to early MIS 6 ( $227_{-8}^{+9}$ ka to $177 \pm 8 \mathrm{ka}$; Kleinmann et al., 2011; Waas et al., 2011). Based on these ages and stratigraphic relations, the underlying fluvial deposits were assumed to have been deposited during MIS 8 and are referred to as Older Middle Terrace deposits (Kleinmann et al., 2011; Rohde et al., 2012), whereas the overlying fluvial deposits were interpreted to have been deposited during MIS 6 (Kleinmann et al., 2011; Waas et al., 2011; Rohde et al., 2012) and form part of the so-called Middle Terraces that accumulated prior to the Saalian Drenthe glaciation.

So far, much research has been carried out on a lithostratigraphical and palynological basis. However, robust numerical ages only exist for the interglacial deposits and the ${ }^{230} \mathrm{U} / \mathrm{Th}$ ages published by Waas et al. (2011) only provide maximum ages for the overlying fluvial deposits. Reliable luminescence ages for the overlying fluvial sediments are still missing, thus hamper the establishment of a chronological framework for these deposits.

\section{METHODS}

\section{Sampling and preparation}

Five luminescence samples were taken in 2012 from the fluvial sediments of the Nachtigall pit (Figs. 2A and 2B). Samples NG1, NG2, NG3 and NG4 were taken from sandy bedform deposits from the eastern part of the Nachtigall pit, while sample NG5 was taken from overbank deposits from the westernmost part of the Nachtigall pit (Figs. 2A and 2B). The ${ }^{230} \mathrm{U} / \mathrm{Th}$ ages determined by Waas et al. (2011) were derived from interglacial deposits about $175 \mathrm{~m}$ northwest of sample NG1 (Fig. 2C).

Sampling and preparation was performed as described in Roskosch et al. (2015). For luminescence measurements, both monomineralic coarse-grained (150-200 $\mu \mathrm{m})$ potassium-rich feldspar minerals and polymineralic finegrained $(4-11 \mu \mathrm{m})$ minerals were used (Table 1). For coarse-grained minerals, small-sized $(2.5 \mathrm{~mm})$ aliquots with about 100-120 grains were created by mounting coarse-grained minerals on $9.8 \mathrm{~mm}$ stainless steel discs using silicone spray as an adhesive. Fine-grained minerals $\left(>10^{5}\right.$ grains; Fuchs et al., 2005, 2013) were mounted on $9.8 \mathrm{~mm}$ aluminum discs from a suspension in acetone.

Sample preparation and luminescence measurements were performed at the Leibniz Institute for Applied Geophysics (Hannover, Germany). For luminescence measurements, an automated Risø TL/OSL reader (DA-20) with a calibrated ${ }^{90} \mathrm{Sr} /{ }^{90} \mathrm{Y}$ beta source $(1.48 \mathrm{GBq}=$ $40 \mathrm{mCi}$ ) was used (Bøtter-Jensen et al., 2010). Feldspar

Table 1. Basic information on fluvial samples that were taken for luminescence dating using feldspar minerals.

\begin{tabular}{lcccccc}
\hline $\begin{array}{l}\text { Sam- } \\
\text { ple }\end{array}$ & $\begin{array}{c}\text { Lab } \\
\text { num. }\end{array}$ & $\begin{array}{c}\text { Longitudes } \\
\text { E }\end{array}$ & $\begin{array}{c}\text { Latitudes } \\
\text { N }\end{array}$ & $\begin{array}{c}\text { Depth Altitude } \\
\text { b.s. } \\
(\mathbf{m})\end{array}$ & $\begin{array}{c}\text { a.s.I. } \\
(\mathbf{m})\end{array}$ & $\begin{array}{c}\text { Grain } \\
\text { size } \\
(\boldsymbol{\mu m})\end{array}$ \\
\hline NG1 & 2665 & $09^{\circ} 24^{\prime} 11.16^{\prime \prime}$ & $51^{\circ} 48^{\prime} 30.83^{\prime \prime}$ & 9.50 & 94.00 & $150-200$ \\
NG2 & 2666 & $09^{\circ} 24^{\prime} 11.16^{\prime \prime}$ & $51^{\circ} 48^{\prime} 30.83^{\prime \prime}$ & 9.00 & 94.50 & $150-200$ \\
NG3 & 2667 & $09^{\circ} 24^{\prime} 10.90^{\prime \prime}$ & $51^{\circ} 48^{\prime} 31.90^{\prime \prime}$ & 6.70 & 96.80 & $150-200$ \\
NG4 & 2668 & $09^{\circ} 24^{\prime} 09.13^{\prime \prime}$ & $5^{\circ} 48^{\prime} 31.49^{\prime \prime}$ & 6.30 & 98.70 & $150-200$ \\
NG5 & 2828 & $09^{\circ} 24^{\prime} 07.90^{\prime \prime}$ & $51^{\circ} 48^{\prime} 31.69^{\prime \prime}$ & 2.50 & 99.00 & $4-11$ \\
\hline
\end{tabular}


signals were stimulated by pulsing by IR light-emitting diodes (LED) either using an external pulsing box (Thomsen et al., 2008a) or a pulsed stimulation attachment (Lapp et al., 2009). A Schott BG39/Corning 7-59 filter combination was used and the feldspar signals were detected in the blue-violet $(320-460 \mathrm{~nm})$ during the offperiods of each pulse cycle, with a delay of $5 \mu \mathrm{s}$ after the LED pulses switched off.

\section{Equivalent dose and dose rate determination}

For equivalent dose $\left(D_{\mathrm{e}}\right)$ determination, 10 aliquots per sample were measured using a pulsed IRSL single aliquot regenerative (SAR) dose protocol (Table 2). A preheat at $250^{\circ} \mathrm{C}$ for $60 \mathrm{~s}$ was used, followed by a pulsed IR stimulation at $50^{\circ} \mathrm{C}$ for $400 \mathrm{~s}$ with $50 \mu \mathrm{s}$ on-time and $200 \mu$ s off-time. Only off-time signal was recorded because it was found to give a stable luminescence signal (Tsukamoto et al., 2006). The pulsed IRSL signal at $50^{\circ} \mathrm{C}$ $\left(\mathrm{IR}_{50}\right)$ was chosen over the elevated temperature post-IR IRSL signal (pIRIR; Thomsen et al., 2008b) because it appears to be more sensitive to light. Comparison of both pulsed IR $_{50}$ and pIRIR 290 results showed that $\operatorname{pIRIR}_{290} D_{\mathrm{e}}$ values were generally higher by about $100-150$ Gy than the pulsed $\mathrm{IR}_{50}$ ones (see Fig. 3B in Roskosch et al., 2015). Jain et al. (2015) compared the residual dose obtained from a modern beach sample using continuous wave $(\mathrm{CW}) \mathrm{IR}_{50}$, pulsed $\mathrm{IR}_{50}$, pIRIR 225 and $\mathrm{pIRIR}_{290}$ signals and a much larger residual dose of $\sim 10$ Gy was obtained from the pIRIR 290 signal than all the other signals (less than $2 \mathrm{~Gy}$ ). This was probably caused by the hard to bleach nature of the pIRIR 290 signal, as has been supported by results of a bleaching study performed by Kars et al. (2014). Based on the above mentioned findings, we focused on the pulsed $\mathrm{IR}_{50}$ signal for $D_{\mathrm{e}}$ determination of the fluvial sediments of this study.

The net feldspar luminescence signal was then calculated from the middle part of the decay curve (21-60 s) after subtracting a late background of the last $50 \mathrm{~s}$ (see Roskosch et al., 2015). The initial part of the decay curve $(0-20 \mathrm{~s})$ was actually reported to give considerably higher fading rates (up to $4.42 \pm 0.46 \%$ ), whereas the middle part was found to show only negligible anomalous fading (see Roskosch et al., 2015).

Aliquots were accepted when they passed for following criteria: recycling ratio limit within $10 \%$ of unity; maximal test dose error $10 \%$; signal intensity larger than 3 sigma above background. We assumed a measurement error of $\pm 2.0 \%$. In order to calculate $D_{\mathrm{e}}$ values, dose response curves were fitted using a single-saturating exponential function.

For dose rate determination, the radionuclide concentration of uranium $\left({ }^{238} \mathrm{U}\right)$, thorium $\left({ }^{232} \mathrm{Th}\right)$ and potassium $\left({ }^{40} \mathrm{~K}\right)$ was determined by high-resolution gamma spectrometry. For coarse-grained feldspar minerals, an internal potassium content of $12.5 \pm 0.5 \%$ was assumed (Huntley and Baril, 1997). The a-value was set to $0.15 \pm 0.05$ for monomineralic coarse-grains (Balescu
Table 2. Pulsed IRSL SAR protocol for feldspar measurements.

\begin{tabular}{cl}
\hline Run & Treatment \\
\hline 1 & Dose \\
2 & Preheat, $60 \mathrm{~s} @ 250^{\circ} \mathrm{C}$ \\
3 & Pulsed IR stimulation, $400 \mathrm{~s} @ 50^{\circ} \mathrm{C}$ \\
4 & Test dose \\
5 & Preheat, $60 \mathrm{~s} @ 250^{\circ} \mathrm{C}$ \\
6 & Pulsed IR stimulation, $400 \mathrm{~s} @ 50^{\circ} \mathrm{C}$ \\
7 & Pulsed IR stimulation, $100 \mathrm{~s} @ 200^{\circ} \mathrm{C}$ \\
8 & Return to step 1 \\
\hline
\end{tabular}

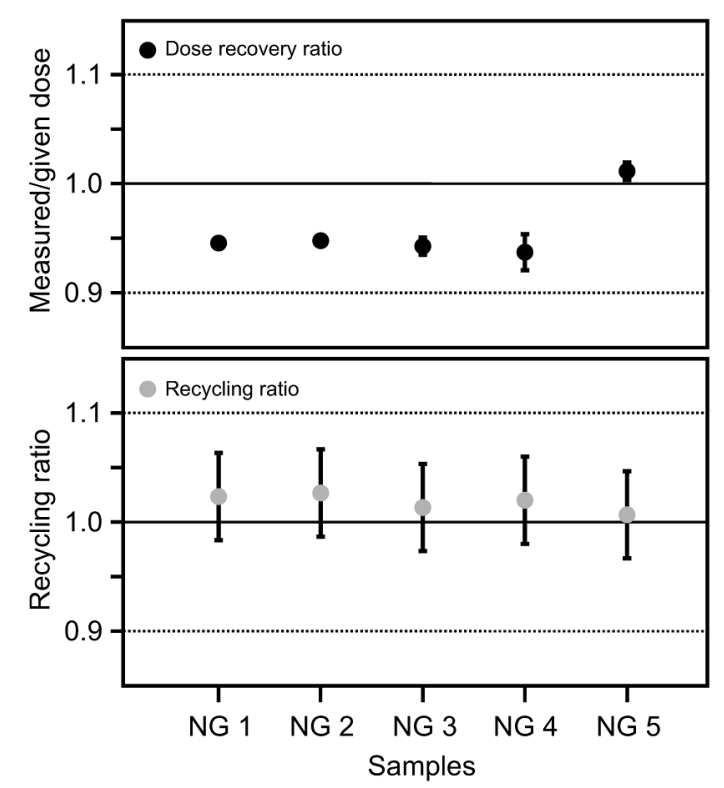

Fig. 3. Results of dose recovery and recycling ratio tests.

and Lamothe, 1994) and $0.08 \pm 0.02$ for polymineralic fine-grains (Lang et al., 2003), respectively. Cosmic radiation was corrected for altitude and sediment thickness after Prescott and Hutton (1994). Water content was measured using samples from the direct surroundings of the luminescence samples, and was 7\% (NG4), 9\% (NG3, $\mathrm{NG} 5), 10 \%$ (NG1) and 11\% (NG2). Based on these values, the overall water content was then set to an average value of $10 \pm 5 \%$ for both the coarse-grained braided river and the fine-grained overbank deposits. Dosimetry results are provided in Table 3.

\section{Performance tests}

Dose recovery experiments on three aliquots of each sample were performed prior to $D_{\mathrm{e}}$ measurements to check for the suitability of the applied SAR protocol under laboratory conditions. Within the Risø TL/OSL reader, aliquots were bleached by IR diodes and then given a similar beta dose that was close to the natural expected one (271 Gy for samples NG1, NG2, NG3 and NG4; 401 Gy for sample NG5). Afterwards, the same 
Table 3. Dosimetry results, dose rates and total dose rate of coarse-grained monomineralic potassium-rich feldspar and polymineralic fine-grained minerals. The a value was $0.15 \pm 0.05$ for monomineralic coarse-grains (Balescu and Lamothe, 1994) and $0.08 \pm 0.02$ for polymineralic fine-grains (cf. Lang et al., 2003). The average water content for all samples was $10 \pm 5 \%$.

\begin{tabular}{|c|c|c|c|c|c|c|c|c|c|}
\hline \multirow[b]{2}{*}{ Sample } & \multicolumn{3}{|c|}{ Dosimetry } & \multicolumn{5}{|c|}{ Dose rates } & \multirow{2}{*}{$\begin{array}{c}\text { Total dose } \\
\text { rate } \\
\text { (mGy/a) }\end{array}$} \\
\hline & $\begin{array}{c}\text { Uranium } \\
(\mathrm{ppm})\end{array}$ & $\begin{array}{c}\text { Thorium } \\
\text { (ppm) }\end{array}$ & $\begin{array}{c}\text { Potassium } \\
(\%)\end{array}$ & $\begin{array}{c}D_{\alpha} \\
\text { (mGy/a) }\end{array}$ & $\begin{array}{c}D_{\beta} \\
\text { (mGy/a) } \\
\end{array}$ & $\begin{array}{c}D_{y} \\
\text { (mGy/a) } \\
\end{array}$ & $\begin{array}{c}\begin{array}{c}D_{\text {internal }} \\
\text { (mGy/a) }\end{array} \\
\end{array}$ & $\begin{array}{c}D_{\text {cosmic }} \\
\text { (mGy/a) }\end{array}$ & \\
\hline NG1 & $1.20 \pm 0.01$ & $4.91 \pm 0.03$ & $197+001$ & $0.10 \pm 0.06$ & $1.49 \pm 0.06$ & $071+005$ & $0.69 \pm 0.09$ & $0.05 \pm 0.01$ & $3.04 \pm 0.13$ \\
\hline NG2 & $1.73 \pm 0.01$ & 7. & & \pm 0.07 & $1.65 \pm 0.06$ & 0.8 & 0.6 & 0.0 & 0.14 \\
\hline VG & & & & 07 & 2.04 & & & & \\
\hline NG4 & $2.43 \pm 0.02$ & 0.03 & 2. & $0.17 \pm 0.07$ & $1.83 \pm 0.06$ & $0.99 \pm$ & $0.69 \pm 009$ & 0.08 & 3.77 \\
\hline NG5 & $2.65 \pm 0.02$ & $11.04 \pm 0.04$ & $2.49 \pm 0.01$ & $0.85 \pm 0.18$ & $2.33 \pm 0.09$ & $1.25 \pm 0.09$ & 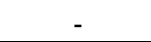 & $0.16 \pm 0.02$ & $4.57 \pm 0.22$ \\
\hline
\end{tabular}

SAR protocol was applied to check if the given dose could be accurately recovered.

Recycling ratio tests were conducted by applying the same dose twice (namely at the beginning and at the end of the measurement). A recycling ratio value that is within $10 \%$ of unity (0.9-1.1; Wallinga et al., 2000) indicates that sensitivity changes which might occur during measurement were successfully corrected. Dose recovery and recycling ratios are presented in Table 4 and Fig. 3.

Recuperation was calculated from a zero-dose point in order to check if thermally-transferred charge from lightinsensitive traps to the luminescence traps occurred. A recuperation level of $\leq 5 \%$ of the natural signal is acceptable (Wallinga et al., 2000). Recuperation values are presented in Table 4.

\section{Fading tests and age calculations}

Feldspar minerals have been observed to show an instability of the luminescence signal, which is also known as anomalous fading (Wintle, 1973; Aitken, 1985; Spooner, 1994). This signal loss over time results in (significantly) lower, thus severely underestimated IRSL ages. Huntley and Lamothe (2001) proposed a fading correction model, which was applied to three aliquots of each of our samples to obtain fading rates (g-values). Based on Thiel et al. (2011) and Buylaert et al. (2012), gvalues below the threshold of $\sim 1.5 \%$ per decade were considered to be laboratory artefacts, thus samples with $\mathrm{g}$-values above this threshold called for fading corrections. For comparison, we calculated g-values for the pIRIR $_{225}$ and pIRIR 290 signals of sample NG5 $(n=3)$. In both cases, g-values were above the threshold of $1.5 \%$ per decade. At the same time, they were higher than the pulsed $\mathrm{IR}_{50}$ g-value of sample NG5 of $0.6 \pm 0.2 \%$ per decade, namely $2.8 \pm 0.2 \%$ per decade $\left(\mathrm{pIRIR}_{225}\right)$ and $2.0 \pm 0.3 \%$ per decade $\left(\right.$ pIRIR $_{290}$; Table 4$)$. This additional test proved that the use of the pulsed $\mathrm{IR}_{50}$ signal did not only benefit from a more stable and faster to bleach signal but also used that part of the signal that showed comparably less fading at least for this sample. Fading rates, fading uncorrected and corrected pulsed $\mathrm{IR}_{50}$, pIRIR $_{225}$ and pIRIR 290 ages are shown in Table 4.

Final ages were calculated taking into account the mean pulsed $\mathrm{IR}_{50} D_{\mathrm{e}}$ values of all accepted aliquots

Table 4. Results of luminescence measurements using the (A) pulsed $I R_{50}$ signal, $(B)$ the pIRIR225 signal, and (C) the pIRIR290 signal, including number of measured aliquots $\left(n_{m}\right)$ and number of aliquots taken for age calculation $\left(n_{c}\right)$, mean recycling ratios, dose recovery ratios, mean recuperation, total dose rates, fading rates ( $g$-values), mean $D_{e}$ values, and fading uncorrected and fading corrected ages. Final ages are written in bold.

\begin{tabular}{|c|c|c|c|c|c|c|c|c|c|}
\hline $\begin{array}{l}\text { (A) } \\
\text { pulsed IR }{ }_{50}\end{array}$ & $\mathrm{n}_{\mathrm{m}} / \mathrm{n}_{\mathrm{c}}$ & $\begin{array}{l}\text { Mean recy- } \\
\text { cling ratio }\end{array}$ & $\begin{array}{l}\text { Dose recov- } \\
\text { ery ratio }\end{array}$ & $\begin{array}{c}\text { Mean re- } \\
\text { cuperation } \\
(\%)\end{array}$ & $\begin{array}{c}\text { Total } \\
\text { dose rate } \\
\text { (mGy/a) }\end{array}$ & $\begin{array}{c}\text { g-value } \\
\text { (\% per } \\
\text { decade) }\end{array}$ & $\begin{array}{c}\text { Mean pulsed } \\
I_{50} D_{e} \\
(G y)\end{array}$ & $\begin{array}{l}\text { Uncorr. } \\
\text { pulsed IR } \\
\text { age (ka) }\end{array}$ & $\begin{array}{l}\text { Corr. pulsed } \\
\text { IR } 50 \text { age (ka) }\end{array}$ \\
\hline$\overline{\text { NG1 }}$ & $10 / 10$ & $1.04 \pm 0.04$ & $0.95 \pm 0.00$ & 5.3 & $3.04 \pm 0.13$ & $2.5 \pm 0.1$ & $177 \pm 3$ & $58 \pm 3$ & $73 \pm 3$ \\
\hline NG2 & $10 / 10$ & $1.03 \pm 0.04$ & $0.95 \pm 0.00$ & 5.1 & $3.39 \pm 0.14$ & $2.7 \pm 0.4$ & $202 \pm 4$ & $59 \pm 3$ & $77 \pm 6$ \\
\hline NG3 & $10 / 10$ & $1.03 \pm 0.04$ & $0.94 \pm 0.04$ & 4.6 & $4.06 \pm 0.14$ & $2.1 \pm 0.4$ & $227 \pm 3$ & $56 \pm 2$ & $68 \pm 5$ \\
\hline NG4 & $10 / 10$ & $1.03 \pm 0.04$ & $0.94 \pm 0.02$ & 4.8 & $3.77 \pm 0.14$ & $2.6 \pm 0.2$ & $216 \pm 2$ & $57 \pm 2$ & $73 \pm 4$ \\
\hline NG5 & $10 / 09$ & $1.02 \pm 0.04$ & $1.01 \pm 0.01$ & 2.8 & $4.57 \pm 0.22$ & $0.6 \pm 0.2$ & $456 \pm 5$ & $100 \pm 5$ & $105 \pm 6$ \\
\hline
\end{tabular}

\begin{tabular}{|c|c|c|c|c|c|c|c|c|c|}
\hline $\begin{array}{l}\text { (B) } \\
\text { pIRIR225 }\end{array}$ & $\mathrm{n}_{\mathrm{m}} / \mathrm{n}_{\mathrm{c}}$ & $\begin{array}{l}\text { Mean recy- } \\
\text { cling ratio }\end{array}$ & $\begin{array}{l}\text { Dose recov- } \\
\text { ery ratio }\end{array}$ & $\begin{array}{c}\text { Mean re- } \\
\text { cuperation } \\
(\%)\end{array}$ & $\begin{array}{c}\text { Total } \\
\text { dose rate } \\
\text { (mGy/a) }\end{array}$ & $\begin{array}{l}\text { g-value } \\
\text { (\% per } \\
\text { decade) }\end{array}$ & $\begin{array}{l}\text { Mean IR } 225 D_{e} \\
(G y)\end{array}$ & $\begin{array}{c}\text { Uncorr. IR } 225 \\
\text { age (ka) }\end{array}$ & $\begin{array}{c}\text { Corr. IR225 age } \\
\text { (ka) }\end{array}$ \\
\hline NG5 & $6 / 6$ & $1.02 \pm 0.06$ & - & 1.74 & $4.57 \pm 0.22$ & $2.8 \pm 0.2$ & $412 \pm 5$ & $90 \pm 4$ & $119 \pm 7$ \\
\hline
\end{tabular}

\begin{tabular}{|c|c|c|c|c|c|c|c|c|c|}
\hline $\begin{array}{l}\text { (C) } \\
\text { pIRIR } 290\end{array}$ & $\mathrm{n}_{\mathrm{m}} / \mathrm{n}_{\mathrm{c}}$ & $\begin{array}{l}\text { Mean recy- } \\
\text { cling ratio }\end{array}$ & $\begin{array}{c}\text { Dose recov- } \\
\text { ery ratio }\end{array}$ & $\begin{array}{l}\text { Mean re- } \\
\text { cuperation } \\
(\%)\end{array}$ & $\begin{array}{c}\text { Total } \\
\text { dose rate } \\
\text { (mGy/a) }\end{array}$ & $\begin{array}{l}\text { g-value } \\
\text { (\% per } \\
\text { decade) }\end{array}$ & $\begin{array}{c}\text { Mean } I_{290} D_{e} \\
(G y)\end{array}$ & $\begin{array}{c}\text { Uncorr. } \\
\text { IR } 290 \text { age (ka) }\end{array}$ & $\begin{array}{c}\text { Corr. } \\
\text { IR }_{290} \text { age (ka) }\end{array}$ \\
\hline$\overline{\mathrm{NG5}}$ & $6 / 6$ & $1.02 \pm 0.06$ & - & 2.19 & $4.57 \pm 0.22$ & $2.0 \pm 0.3$ & $474 \pm 27$ & $103 \pm 7$ & $125 \pm 12$ \\
\hline
\end{tabular}


(Table 4). The age error of an uncorrected pulsed $\mathrm{IR}_{50}$ age was calculated by taking the 1-sigma standard error of the obtained $D_{\mathrm{e}}$ value. The age error of a corrected pulsed $\mathrm{IR}_{50}$ age was calculated by adding the uncorrected age error to the mean age error.

\section{RESULTS}

For all luminescence samples, dose response curves and frequency- $D_{\mathrm{e}}$ histograms as well as radial plots were

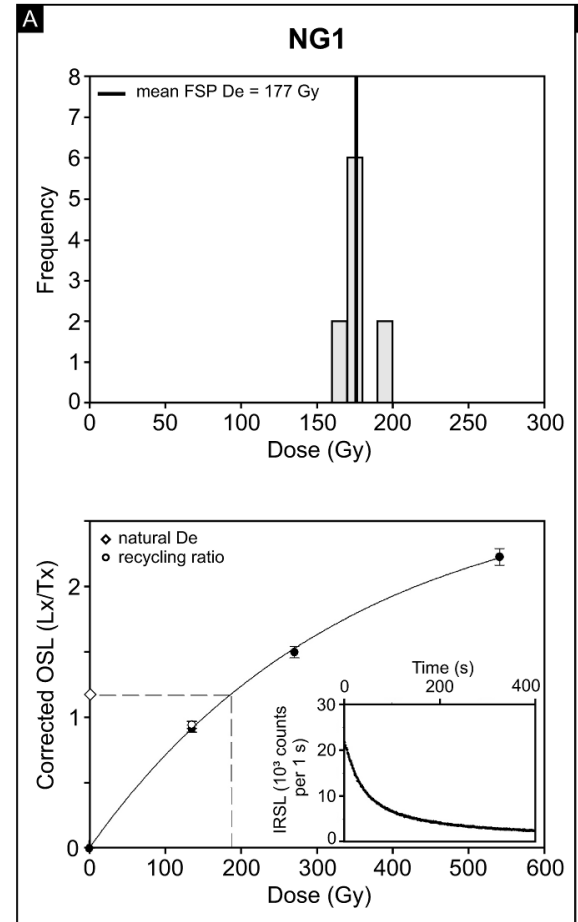

D
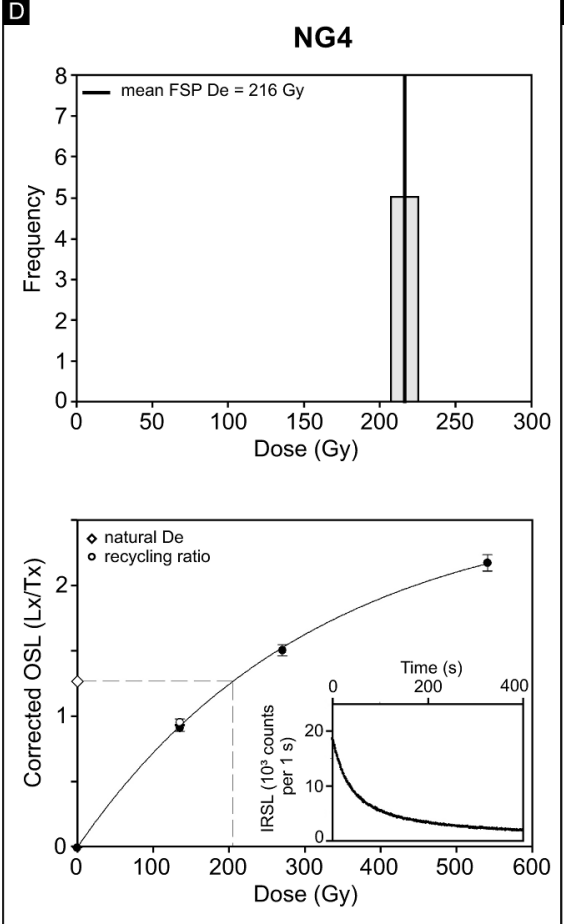
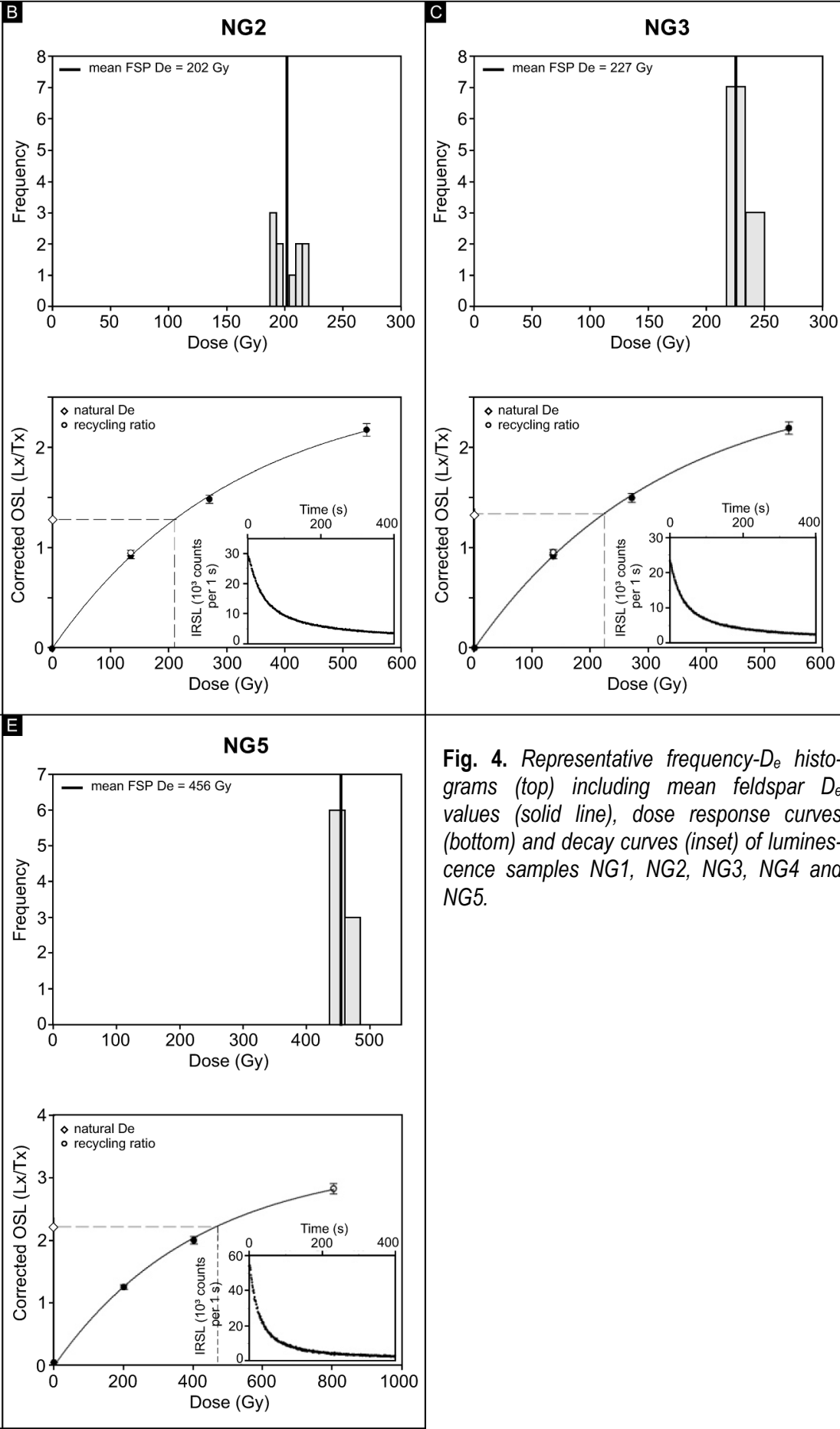

Fig. 4. Representative frequency- $D_{e}$ histograms (top) including mean feldspar $D_{e}$ values (solid line), dose response curves (bottom) and decay curves (inset) of luminescence samples NG1, NG2, NG3, NG4 and NG5. 


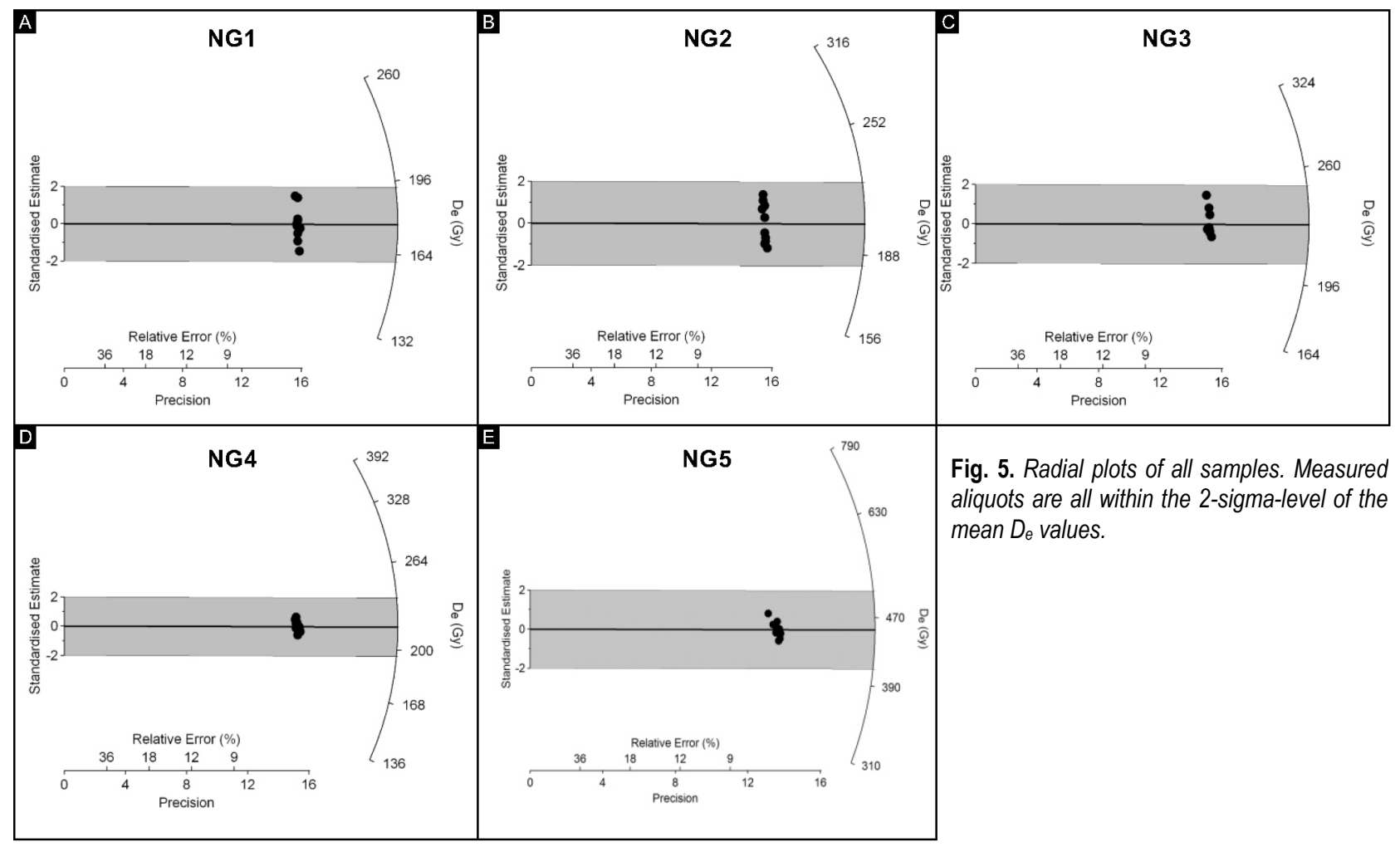

created based on the accepted aliquots (Figs. 4 and 5). Dose response curves are characterised by single saturating exponential growth. For the frequency- $D_{\mathrm{e}}$ histograms, bin widths are close to the median of $D_{\mathrm{e}}$ values as suggested by Lepper et al. (2000). Frequency- $D_{\mathrm{e}}$ histograms are characterised by very narrow and tight $D_{\mathrm{e}}$ distributions (Fig. 4) and radial plots are characterised by $D_{\mathrm{e}}$ values which are all within the 2-sigma range of the mean

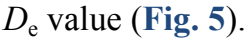

Results of dose recovery and recycling ratio tests are all satisfying and in the acceptable range of $10 \%$ of unity (0.9-1.1; Fig. 3; Wallinga et al., 2000). Dose recovery ratios range between $0.94 \pm 0.04(\mathrm{NG} 3)$ to $1.01 \pm 0.01$ (NG5; Table 4). These results indicate that the applied SAR protocol is able to reliably recover a given dose, creating consistent $D_{\mathrm{e}}$ values. Recycling ratios range between $1.02 \pm 0.04$ (NG5) and $1.04 \pm 0.04$ (NG1; Table 4). Sensitivity changes that might occur during measurements were successfully corrected by the chosen SAR protocol. Recuperation values were all $\leq 5 \%$ of the natural signal (Table 4) and therefore in an acceptable range (Wallinga et al., 2000).

The obtained g-values for all samples were between $2.1 \pm 0.4 \%$ per decade (NG3) and $2.7 \pm 0.04 \%$ per decade (NG2) for monomineralic coarse-grains and $0.6 \pm 0.2 \%$ per decade (NG5) for polymineralic fine-grains. Due to their higher g-values, the determined fading uncorrected pulsed $\mathrm{IR}_{50}$ ages of the coarse-grained samples NG1 to NG4 needed a subsequent fading correction (Thiel et al., 2011; Buylaert et al., 2012). Fading uncorrected and corrected pulsed $\mathrm{IR}_{50}$ ages are presented in Table 4. Dose rate results gave values ranging from $3.04 \pm 0.13 \mathrm{mGy} / \mathrm{a}$ (NG1) to $4.57 \pm 0.22 \mathrm{mGy} / \mathrm{a}$ (NG5; Table 3 ).

Final depositional ages point to two major depositional phases. Sample NG5 gave a fading uncorrected pulsed $\mathrm{IR}_{50}$ age of $100 \pm 5 \mathrm{ka}$, indicating a Late Pleistocene (Early Weichselian) deposition, correlating with MIS 5d. Samples NG1 to NG4 gave fading corrected pulsed $\mathrm{IR}_{50}$ ages ranging from $77 \pm 6 \mathrm{ka}$ (NG2) to $68 \pm 5 \mathrm{ka}$ (NG3), pointing to a Late Pleistocene (Early Weichselian to Early Pleniglacial) deposition which can be correlated with late MIS $5 \mathrm{~b}$ to MIS 4. These ages reveal a chronological gap of about $12 \mathrm{ka}$ between the Late Pleistocene MIS 5d and MIS $5 \mathrm{~b}$ to MIS 4 fluvial sediments which seems to coincide with the major (erosional) bounding surface of about $9 \mathrm{~m}$, separating the western and older from the eastern and younger fluvial sediments (Figs. 2A and 2B). Interpretation of the large-scale terrace architecture led to the assumption that the fluvial deposits display laterally attached terraces (Winsemann et al., 2015), which form when either both rates of fluvial aggradation and degradation are balanced or the generation of accommodation is low (Archer et al., 2011). 


\section{DISCUSSION}

\section{Luminescence results: reliable and robust?}

Since feldspar minerals are known to suffer from anomalous fading, it is recommended to use only those parts of the IRSL signal which are less fading-dependent (e.g., Thiel et al., 2011). We followed the approach by Roskosch et al. (2015) who stated that the middle part of the decay curve of the pulsed $I_{50}$ signal is characterised by a more stable, thus less fading-dependent luminescence signal when compared to other (parts of the) signals. The results of the additionally applied fading test of sample NG5 using the pulsed IR $_{50}$, pIRIR 225 and pIRIR 290 signals suggests that the pulsed $\mathrm{IR}_{50}$ signal is more stable than the pIRIR $_{225}$ and pIRIR 290 signal (Table 4), confirming the use of the pulsed $\mathrm{IR}_{50}$ signal. However, the applied fading tests for the other four samples indicated that some effect of anomalous fading was still present within our samples and fading correction seemed to be necessary for most of the samples. Table 4 shows that fading uncorrected pulsed $\mathrm{IR}_{50}$ ages underestimated the fading corrected pulsed $\mathrm{IR}_{50}$ ages by up to about $18 \mathrm{ka}$ (NG2). So far, correction models for older samples (e.g. Lamothe et al., 2003; Kars et al., 2008) have not been tested on an accurate basis. Huntley and Lamothe (2001) strongly advise against using their correction model for (comparably) older deposits because their model is just applicable to the 'linear' part of the decay curve, thus (comparably) younger sediments. However, we followed the promising studies of Buylaert et al. (2011) and Roskosch et al. (2015), who successfully generated fading corrected ages of Middle Pleistocene (Elsterian, Saalian, Eemian) sediments. Consequently, we believe that the effect of age underestimation based on the occurrence of anomalous fading was minimized as far as possible by both using a more stable luminescence signal (Tsukamoto et al., 2006) and applying a suitable fading correction model (Huntley and Lamothe, 2001).

Age overestimation is commonly linked to the occurrence of insufficient bleaching of the luminescence signal prior to deposition. We additionally performed bleaching tests for the $\mathrm{CW} \mathrm{IR}{ }_{50}$ (obtained as a part of the pIRIR ${ }_{225}$ sequence) and pIRIR 225 signals and the pulsed $\mathrm{IR}_{50}$ signals of samples NG2 and NG5. Natural aliquots of both samples were bleached in a Hönle SOL2 solar simulator for different bleaching durations between 0 and 6 hours and the remaining sensitivity-corrected signal intensity was plotted against the natural signal intensity. The results clearly demonstrate that the pulsed $\mathrm{IR}_{50}$ signal is much faster to bleach (sample NG5) or bleaches in a similar way (sample NG2) as the pIRIR 225 signal, although this signal is harder to bleach than the $\mathrm{CW} \mathrm{IR}_{50}$ signal (Fig. 6). Taking the remaining signal after 30 minutes bleaching as an example, the pulsed $\mathrm{IR}_{50}$ signal for both samples bleached to $\sim 4-6 \%$ of the natural, whereas the pIRIR 225 signal has $6-11 \%$ remaining signal. Since the pulsed $\mathrm{IR}_{50}$ signal is considered to be much more light-sensitive than other elevated temperature pIRIR signals (e.g. Jain et al., 2015; Roskosch et al., 2015) but has not been used widely so far (e.g. Roskosch et al., 2015), our objective was to use this stable, less fadingdependent and faster bleachable signal in order to provide new pulsed $\mathrm{IR}_{50}$ ages. However, we only conducted comparative bleaching measurements of different IRSL signals on one coarse-grained sample (sample NG2) which is probably more prone to insufficient bleaching than the fine-grained sample of NG5. A definite exclusion of insufficient bleaching for all of the coarse-grained samples NG1 to NG4 can therefore not be made. However, as the last depositional ages of the coarse-grained samples are consistent within their age errors, we conclude that insufficient bleaching does not seem to be of great significance for these samples. The comparison of ages obtained from different IRSL signals for sample NG5 also demonstrated that although the fading corrected pIRIR ${ }_{225}$ and pIRIR 290 ages slightly overestimated the pulsed IR $_{50}$ age, the three ages agreed within their 2-sigma uncertain-
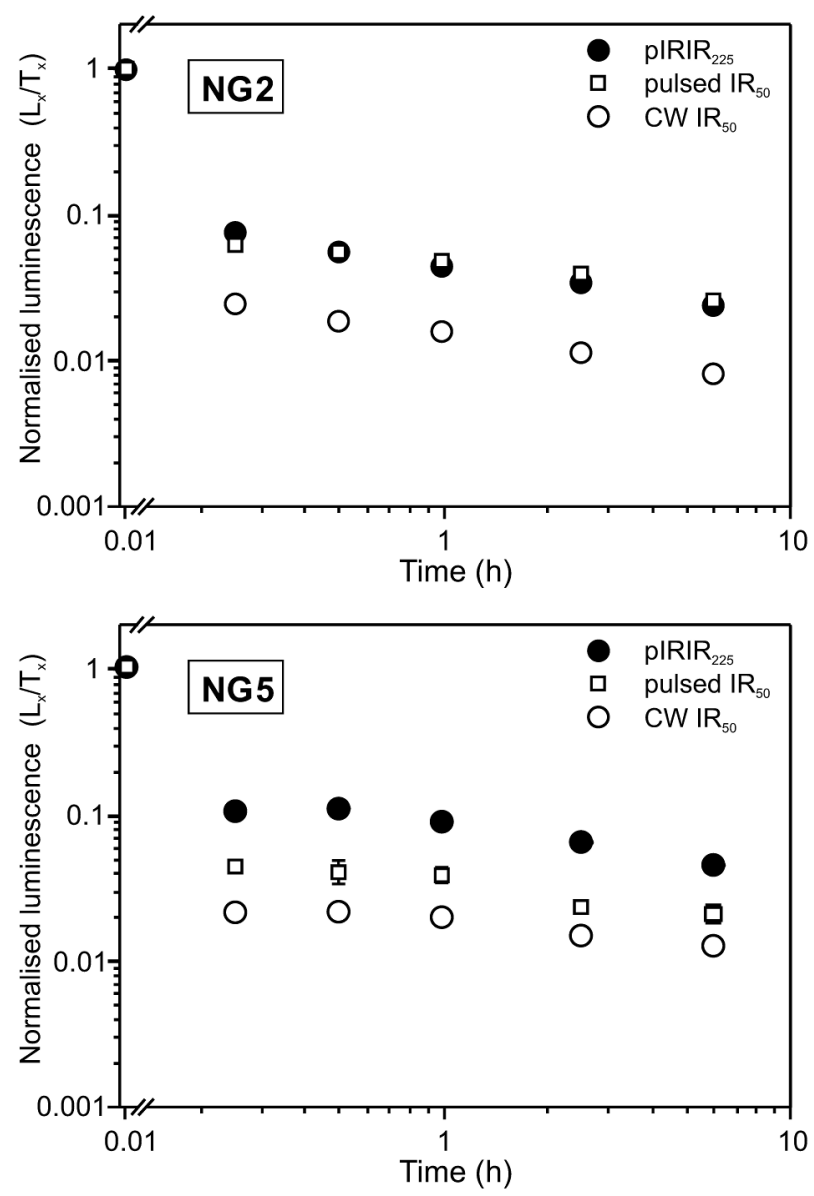

Fig. 6. Results of bleaching tests for the CW IR 50 (white circle), pIRIR 225 (black circle) and pulsed IR 50 signals (white square) of sample NG2 and NG5, clearly showing that the pulsed IR50 signal bleaches a lot faster than the pIRIR225 signal, which is considered to be even harder bleachable than the CW IR 50 signal. 


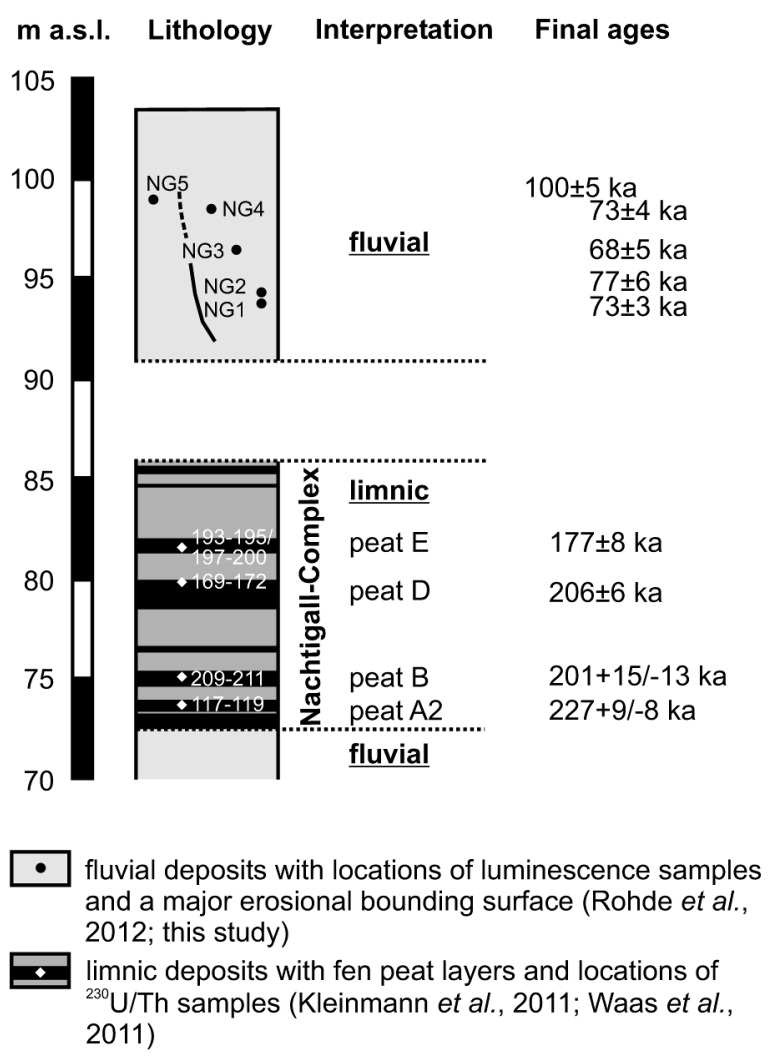

Fig. 7. Schematic log of the investigated deposits of the Nachtigall pit, showing lithology, interpretation and final pulsed IR50 and ${ }^{230} \mathrm{U} / \mathrm{Th}$ ages. The major erosional bounding surface is indicated by a (dashed) line (see Fig. 2B). The altitudes of the fluvial sediments are derived from Rohde et al. (2012) and from GPS measurements of the recent Nachtigall pit (this study). The altitudes and lithology boundaries of the interglacial Nachtigall-Complex deposits were based on Kleinmann et al. (2011) and Waas et al. (2011) who derived their data from a core drilled about $175 \mathrm{~m}$ northwest of sample NG1 (see Fig. 2C). Here, altitude of the surface during drilling was $108.55 \mathrm{~m}$ a.s.l.

ties (Table 4B and 4C). Again, this suggests that the bleaching condition prior to deposition does not seem to have been a major problem for sample NG5.

\section{Stratigraphic significance of the luminescence results}

Our ages are stratigraphically agree with each other and are also consistent with the ${ }^{230} \mathrm{U} / \mathrm{Th}$ ages of the underlying interglacial deposits, which were correlated with MIS 7c to early MIS 6 (Waas et al., 2011; Fig. 7). The obtained luminescence ages are of great value when evaluating the previously established Middle to Late Pleistocene fluvial depositional model (e.g. Rohde et al., 2012). On the one hand, the occurrence of fluvial sediments which were assumed to be younger than the underlying interglacial sediments could be proven. However, fluvial deposition did not occur during the (Middle Pleistocene) Saalian, as had previously been assumed (e.g. Rohde et al., 2012), but during the (Late Pleistocene) Early Weich- selian to Early Pleniglacial (MIS 5d, late MIS 5b to MIS 4; Table 4). This is comparable to the study of Cordier et al. (2014) who also found by using luminescence dating techniques that deposits of a presumably Saalian age were actually deposited during the Weichselian.

On the other hand, the occurrence of Late Pleistocene (Weichselian) fluvial deposits was expected to occur only in the floodplain area of River Weser (cf. Rohde et al., 2012). The previous depositional model has to be revised due to the obtained luminescence ages of samples NG1 to NG4, pointing to an Early Weichselian to Early Pleniglacial deposition for this part of the pit. It is, however, likely that the adjacent valley area is characterised by gravelly and sandy fluvial sediments (referred to as Lower Terrace deposits, cf. Rohde et al., 2012), which had been deposited afterwards and which may be underlain by Saalian fluvial deposits, as has been described by Rohde et al. (2012). So far, these fluvial sediments have not been dated. Therefore, the Late Pleistocene sedimentary complex seems to have been subdivided into two fluvial sediment bodies.

The first phase of fluvial aggradation occurred around $100 \pm 5 \mathrm{ka}$, correlating with MIS 5d, whereas the second phase of fluvial aggradation was found to have occurred from $77 \pm 6$ to $68 \pm 5 \mathrm{ka}$, mainly correlating with late MIS $5 \mathrm{~b}$ to MIS 5a (Table 4). It may, however, have continued until early MIS 4 . The timing of vertical erosion (incision) of about $9 \mathrm{~m}$ (Figs. 2A and 2B) is difficult to determine but is likely to have occurred somewhere during MIS 5d to MIS 5c, which would be in accordance with data from France (Moselle and Meurthe: e.g. Cordier et al., 2010; Somme, Seine, Yonne: Antoine, 1994; Antoine et al., 2007) and Germany (Leine valley: Winsemann et al., 2015)

The luminescence dating results have shown that comparison with independent age control is of great importance. Given the important value of the obtained luminescence ages, additional numerical dating approaches need to be performed and thus complement the chronostratigraphic framework of the deposits of the Nachtigall pit.

\section{CONCLUSIONS}

We present new luminescence ages from five fluvial samples of the Nachtigall pit in the southern Weser valley in northwestern Germany. Luminescence measurements on monomineralic feldspar coarse-grains and polymineralic fine-grains were performed using a pulsed IRSL SAR protocol. Luminescence ages are consistent with ${ }^{230} \mathrm{U} / \mathrm{Th}$ ages of underlying interglacial deposits (Waas et al., 2011).

- Luminescence samples passed required performance tests, and results of dose recovery and recycling ratio tests as well as recuperation values were satisfyingly acceptable. 
- Additional bleaching tests for samples NG2 and NG5, and fading testes and measurements using the pI$\mathrm{RIR}_{225}$ and pIRIR 290 signals were performed on sample NG5. The effect of insufficient bleaching of the coarse-grained sample cannot be entirely ruled out because only one sample was measured. However, as the ages for all coarse-grained samples agree within their age errors, insufficient bleaching is considered to be a random feature and assumed to only play a negligible role. Comparison with the obtained g-values of the pulsed $I_{50}$ signal showed that the pulsed $I_{50}$ signal does bleach faster (sample NG5) or bleaches in a smiliar way (sample NG2). For sample NG5, $D_{\mathrm{e}}$ values were in the order of pIRIR $225<$ pulsed $\mathrm{IR}_{50}<$ pIRIR $_{290}$ but all fading corrected ages agreed within their 2-sigma uncertainties. Based on these observations, insufficient bleaching is not considered a major issue for the studied samples.

- Numerical dating results point to two phases of fluvial aggradation, which occurred during the Late Pleistocene. One polymineralic fine-grained sample (NG5) was derived from fine-grained overbank deposits from the western part of the succession and gave an uncorrected feldspar age of $100 \pm 5 \mathrm{ka}$ (MIS 5d; Early Weichselian). Four coarse-grained samples (NG1, NG2, NG3, NG4) were derived from medium- to fine-grained sandy deposits, interbedded into gravel sheet deposits, lateral and downstream accretion macroforms in the eastern part of the succession, giving corrected feldspar ages ranging from $77 \pm 6$ ka to $68 \pm 5 \mathrm{ka}$ (late MIS $5 \mathrm{~b}$ to MIS 4; Early Weichselian to Early Pleniglacial).

- The fluvial deposits overlying the NachtigallComplex are indeed younger as has previously been assumed (Rohde et al., 2012). However, the obtained luminescence ages contradict an expected Middle Pleistocene Saalian deposition. The depositional model for this part of the Nachtigall pit has to be revised, indicating the possible occurrence of a solely Late Pleistocene laterally attached terrace complex. This complex is characterised by a major erosional bounding surface which separates the western and older from the eastern and younger fluvial deposits.

\section{ACKNOWLEDGEMENTS}

We gratefully acknowledge financial support by the LU Hannover. Constructive comments by two anonymous reviewers are highly appreciated and helped to improve the manuscript. Many thanks are due to J.-U. Müller of Bauunternehmen Jens Müller $\mathrm{GmbH}$ for permitting us to work on his property at the Nachtigall pit. Sincere thanks are given to P. Rohde for drawing our attention to the Nachtigall pit, for assistance during field work, for fruitful discussions and personal comments on the draft version of the manuscript. J. Lang, J. Lepper, A. Osman, L. Pollok, A. Weitkamp and J. Winsemann are thanked for field work and helpful discussion, and S. Riemenschneider is thanked for technical support in the luminescence laboratory.

\section{REFERENCES}

Aitken MJ, 1985. Thermoluminescence Dating. Academic Press, London: $359 \mathrm{pp}$

Antoine P, 1994. The Somme valley terrace system (northern France); a model of river response to Quaternary climatic variations since 800,000 BP. Terra Nova 6(5): 453-464, DOI 10.1111/j.13653121.1994.tb00889.x.

Antoine P, Limondin Lozouet N, Chaussé C, Lautridou J-P, Pastre J-F, Auguste P, Bahain, J-J, Falguères, C and Galehb B, 2007. Pleistocene fluvial terraces from northern France (Seine, Yonne, Somme): sysnthesis, and new results from interglacial deposits. Quaternary Science Reviews 26(22-24): 2701-2723, DOI 10.1016/j.quascirev.2006.01.036.

Archer SG, Reynisson RF and Schwab AM, 2011. River terraces in the rock record: An overlooked landform in geological interpretation. In: Davidson SK., Leleu S and North CP, eds., From River to Rock Record: The Preservation of Fluvial Sediments and their Subsequent Interpretation. SEPM, Special Publication, 97: 63-85.

Balescu S and Lamothe M, 1994. Comparison of TL and IRSL age estimates of feldspar coarse grains from waterlain sediments. Quaternary Science Reviews 13(3-7): 437-444, DOI 10.1016/02773791(94)90056-6.

Briant RM, Bates MR, Schwenninger J-L and Wenban-Smith F, 2006. An optically stimulated luminescence dated Middle to Late Pleistocene fluvial sequence from the western Solent Basin, southern England. Journal of Quaternary Science 21(5): 507-523, DOI 10.1002/jqs. 1035 .

Busschers FS, van Balen RT, Cohen KM, Kasse C, Weerts HJT, Wallinga $\mathrm{J}$ and Bunnik F, 2008. Response of the Rhine-Meuse fluvial system to Saalian ice-sheet dynamics. Boreas 37(3): 377-398, DOI 10.1111/j.1502-3885.2008.00025.x.

Buylaert J-P, Huot S, Murray A and van den Haute P, 2011. Infrared stimulated luminescence dating of an Eemian (MIS 5e) site in Denmark using K-feldspar. Boreas 40(1): 46-56, DOI 10.1111/j.1502-3885.2010.00156.x.

Buylaert J-P, Jain M, Murray AS, Thomsen KJ, Thiel C and Sohbati R, 2012. A robust feldspar luminescence dating method for Middle and Late Pleistocene sediments. Boreas 41(3): 435-451, DOI 10.1111/j.1502-3885.2012.00248.x.

Buylaert J-P, Murray AS, Gebhardt AC, Sohbati R, Ohlendorf C, Thiel C, Wastegård S, Zolitschka B and The PASADO Science Team, 2013. Luminescence dating of the PADADO core 5022-1D from Laguna Potrok Aike (Argentinia) using IRSL signal from feldspar. Quaternary Science Reviews 71: 70-80, DOI 10.1016/j.quascirev.2013.03.018.

Bøtter-Jensen L, Thomsen KJ and Jain M, 2010. Review of optically stimulated luminescence (OSL) instrumental developments for retrospective dosimetry. Radiation Measurements 45(3-6): 253-257, DOI 10.1016/j.radmeas.2009.11.030.

Carthaus E, 1886. Mitteilungen über die Triasformation im nordöstlichen Westfalen und in einigen angrenzenden Gebieten (Notes on the Triassic formation in northeastern Westphalia and in some adjacent areas). $\mathrm{PhD}$ thesis, University of Würzburg: 69pp (in German).

Choi S-W, Preusser F and Radtke U, 2007. Dating of river Rhine Lower Terrace sediments from the Middle Rhine area, Germany. Quaternary Geochronology 2(1-4): 137-142, DOI 10.1016/j.quageo.2006.03.005.

Cordier S, Frechen M and Tsukamoto S, 2010. Methodological aspects on luminescence dating of fluvial sands from the Moselle Basin, Luxembourg. Geochronometria 35(1): 67-74, DOI 10.2478/v10003-010-0006-4.

Cordier S, Frechen M and Harmand D, 2014. Dating fluvial erosion: fluvial response to climate change in the Moselle catchment 
(France, Germany) since the Late Saalian. Boreas 43(2): 450-468, DOI 10.1111/bor.12057.

Dechen $\mathrm{H}$ von, 1884. Erläuterung zur geologischen Karte der Rheinprovinz und der Provinz Westfalen sowie einiger angrenzenden Gegenden (Explanatory notes on the geological map of the Rhine Province and the Province of Westphalia and some adjacent areas). Bonn, Henry: 933pp (in German).

Frechen M, Ellwanger D, Rimkus D and Techmer A, 2008. Timing of Medieval Fluvial Aggradation at Bremgarten in the Southern Upper Rhine Graben - a Test for Luminescence Dating. E\&G Quaternary Science Journal 57(3-4): 411-432, DOI 10.3285/eg.57.34.8 .

Frechen M, Ellwanger D, Hinderer M, Lämmermann-Bartel J, Neeb I and Techmer A, 2010. Late Pleistocene fluvial dynamics in the Hochrhein Valley and in the Upper Rhine Graben: chronological frame. International Journal of Earth Sciences (Geologische Rundschau) 99(8): 1955-1974, DOI 10.1007/s00531-009-0482-9.

Fromm K, 1989. Paläomagnetische Datierung hochgelegener SandKies-Terrassen der Weser (Paleomagnetic Dating of Pleistocene Sand and Gravel Terraces of the Weser River high morphologic Position). E\&G Quaternary Science Journal 39(1): 57-61, DOI 10.3285/eg.39.1.07.

Fuchs M and Lang A, 2001. OSL dating of coarse-grain fluvial quartz using single-aliquot protocols on sediments from NE Peloponnese, Greece. Quaternary Science Reviews 20(5-9): 783-787, DOI 10.1016/S0277-3791(00)00040-8.

Fuchs M, Straub J and Zöller L, 2005. Residual luminescence signals of recent river flood sediments: A comparison between quartz and feldspar of fine- and coarse-grain sediments. Ancient TL 23(1): 25-30.

Fuchs M, Kreutzer S, Rousseau D-D, Antoine P, Hatté C, Lagroix F, Moine O, Gauthier C, Svoboda J and Lisá L, 2013. The loess sequence of Dolní Věstosnice, Czech Republic: A new OSL-based chronology of the Last Climatic Cycle. Boreas 42(3): 664-677, DOI 10.1111/j.1502-3885.2012.00299.x.

Gemmell AMD, 1997. Fluctuations in the thermoluminescence signal of suspended sediment in an alpine glacial meltwater stream. Quaternary Science Reviews 16(3-5): 281-290, DOI 10.1016/S02773791(96)00087-X.

Grupe O, 1912. Erläuterungen zur Geologischen Karte von Preußen und benachbarten Bundesstaates 1:25 000, Blatt 4122 Holzminden (Explanatory notes on the geological map of Prussia and adjacent states 1:25 000, sheet 4122 Holzminden). Königlich-Preußische Geologische Landesanstalt, Berlin: 95pp (in German).

Grupe O, 1929. Erläuterungen zur Geologische Karte von Preußen und benachbarten deutschen Ländern 1:25 000, Blatt 4122 Holzminden (Explanatory notes on the geological map of Prussia and adjacent German states 1:25 000, sheet 4122 Holzminden). Preußische Geologische Landesanstalt, Berlin: 71pp (in German).

Huntley DJ and Baril MR, 1997. The K content of the K-feldspars being measured in optical dating or in thermoluminescence dating. Ancient TL 15(1): 11-13.

Huntley DJ and Lamothe M, 2001. Ubiquity of anomalous fading in Kfeldspars and the measurement and correction for it in optical dating. Canadian Journal of Earth Sciences 38(7): 1093-1106, DOI 10.1139/e01-013.

Jain M, Murray AS and Bøtter-Jensen L, 2004. Optically stimulated luminescence dating: how significant is incomplete light exposure in fluvial environments? Quaternaire 15(1-2): 143-157.

Jain M, Buylaert JP, Thomsen KJ and Murray AS, 2015. Further investigations on 'non-fading' in K-Feldspar. Quaternary International 362: 3-7, DOI 10.1016/j.quaint.2014.11.018.

Kars RH, Reimann T, Ankjærgaard C and Wallinga J, 2014. Bleaching of the post-IR IRSL signal: new insights for feldspar luminescence dating. Boreas 43(4): 780-791, DOI 10.1111/bor.12082.

Kars RH, Wallinga $\mathrm{J}$ and Cohen KM, 2008. A new approach towards anomalous fading correction for feldspar IRSL dating - tests on samples in field saturation. Radiation Measurements 43(2-6): 786-790, DOI 10.1016/j.radmeas.2008.01.021.

Kleinmann A, Müller H, Lepper J and Waas D, 2011. Nachtigall: A continental sediment and pollen sequence of the Saalian Complex in NW-Germany and its relationship to the MIS-framework. Quaternary International 241(1-2): 97-110, DOI 10.1016/j.quaint.2010.10.005.

Koken E, 1901. Beiträge zur Kenntnis des schwäbischen Diluviums (Contributions to the knowledge of the Swabian Diluvium). Neues Jahrbuch für Mineralogie, Geologie und Paläontologie 14: 120 170 (in German).

Krbetschek MR, Degering D and Alexowsky W, 2008. InfrarotRadiofluoreszenz-Alter (IR-RF) unter-saalezeitlicher Sedimente Mittel- und Ostdeutschlands (Infrared radiofluorescence ages (IRRF) of Lower Saalian sediments from Central and Eastern Germany). Zeitschrift der Deutschen Gesellschaft für Geowissenschaften 159(1): 133-140, DOI 10.1127/1860-1804/2008/0159-0133.

Lamothe M, Auclair M, Hanazaoui C and Huot S, 2003. Towards a predictions of long-term anomalous fading of feldspar IRSL. Radiation Measurements 37(4-5): 493-498, DOI 10.1016/S13504487(03)00016-7.

Lang A, Hatte C, Rousseau D-D, Antoine P, Fontugne M, Zöller L and Hambach U, 2003. High-resolution chronologies for loess: comparing AMS ${ }^{14} \mathrm{C}$ and optical dating results. Quaternary Science Reviews 22(10-13): $\quad 953-959, \quad$ DOI $10.1016 / \mathrm{S} 0277-$ 3791(03)00035-0.

Lapp T, Jain M, Ankjærgaard C and Pirzel L, 2009. Development of pulsed stimulation and photon timer attachments to the Risø TL/OSL reader. Radiation Measurements 44(5-6): 571-575, DOI 10.1016/j.radmeas.2009.01.012.

Lauer T, Frechen M, Hoselmann C and Tsukamoto S, 2010. Fluvial aggradation phases in the Upper Rhine Graben - new insights by quartz OSL dating. Proceedings of the Geologists' Association 121(2): 154-161, DOI 10.1016/j.pgeola.2009.10.006.

Lauer T, Krbetschek M, Frechen M, Tsukamoto S, Hoselmann C and Weidenfeller M, 2011. Infrared radiofluorescence (IR-RF) dating of Middle Pleistocene fluvial archives of the Heidelberg Basin (southwest Germany). Geochoronometria 38(1): 23-33, DOI 10.2478/s13386-011-0006-9.

Lepper J, 1991. Beiheft zur Geologischen Wanderkarte, Mittleres Weserbergland mit Naturpark Solling-Vogler 1:100 000 (Supplement to the geological trail map, Middle Weserberglang area including Nature Park Solling-Vogler 1:100 000). Bericht der Naturhistorischen Gesellschaft Hannover 10: 58pp (in German).

Lepper J, 1998. Tongrube Nachtigall des Ziegelwerkes Buch bei Albaxen (Clay pit Nachtigall of the brickyard Buch at Albaxen). In: Feldmann L and Meyer K-D, eds., Quartär in Niedersachsen (The Quaternary of Lower Saxony). Deuqua-Exkursionsführer, Hannover: 205pp (in German).

Lepper J and Mengeling H, 1990. Geologische Wanderkarte, Mittleres Weserbergland mit Naturpark Solling-Vogler 1:100 000 (Geological trail map, Middle Weserbergland area including Nature Park Solling-Vogler 1:100 000). Zweckverband Naturpark SolingVogler in Zusammenarbeit mit dem Niedersächsischen Landesamt für Bodenforschung (in German).

Lepper L, Larsen NA and McKeever SWS, 2000. Equivalent dose distribution analysis of Holocene eolian and fluvial quartz sands from Central Oklahoma. Radiation Measurements 32(5-6): 603608, DOI 10.1016/S1350-4487(00)00093-7.

Lewis SG, Maddy D and Scaife RG, 2001. The fluvial system response to abrupt climate change during the last cold stage: the Upper Pleistocene River Thames fluvial succession at Ashton Keynes, UK. Global Planetary Change 28(1-4): 341-359, DOI 10.1016/S0921-8181(00)00083-7.

Mangelsdorf P, 1981. Quartärgeologische und paläobotanische Untersuchungen in der Tongrupe „Nachtigall“ N Höxter/Weser (Quaternary geological and palaeobotanical studies in the clay pit "Nachtigall" N Höxter/Weser). Unpublished diploma thesis, University of Hannover: 63pp (in German).

Molodkov A, 2012. Cross-check of the dating results obtained by ESR and IR-OSL methods: Implications for the Pleistocene palaeoenvironmental reconstructions. Quaternary Geochronology 10: 188194, DOI 10.1016/j.quageo.2012.02.005.

Murray AS, Olley JM and Caitcheon GG, 1995. Measurement of equivalent doses in quartz from contemporary water-lain sediments us- 
ing optically stimulated luminescence. Quaternary Science Reviews 14(4): 365-371, DOI 10.1016/0277-3791(95)00030-5.

Murray AS, Thomsen KJ, Masuda N, Buylaert J-P and Jain M, 2012. Identifying well-bleached quartz using the different bleaching rates of quartz and feldspar luminescence signals. Radiation Measurements 47(9): 688-695, DOI 10.1016/j.radmeas.2012.05.006.

Novothny Á, Frechen M, Horváth E, Bradák B, Oches EA, McCoy WD and Stevens T, 2009. Luminescence and amino acid racemization chronology of the loess-paleosol sequence at Süttő, Hungary. Quaternary International 198(1-2): 62-76, DOI 10.1016/j.quaint.2008.01.009.

Olley JM, Caitcheon GG and Roberts RG, 1999. The origin of dose distributions in fluvial sediments, and the prospect of dating single grains from fluvial deposits using optically stimulated luminescence. Radiation Measurements 30(2): 207-217, DOI 10.1016/S1350-4487(99)00040-2.

Prescott JR and Hutton JT, 1994. Cosmic ray contribution to dose rates for luminescence and ESR dating: large depths and long-term time variations. Radiation Measurements 23(2-3): 497-500, DOI 10.1016/1350-4487(94)90086-8.

Rittenour TM, 2008. Luminescence dating of fluvial deposits: applications to geomorphic, palaeoseismic and archaeological research. Boreas 37(4): 613-635, DOI 10.1111/j.1502-3885.2008.00056.x.

Rittenour TM, Goble RJ and Blum MD, 2005. Development of an OSL chronology for Late Pleistocene channel belts in the lower Mississippi valley, USA. Quaternary Science Reviews 24(23-24): 25392554, DOI 10.1016/j.quascirev.2005.03.011.

Rohde P, 1983. Geologische Karte von Niedersachsen 1:25 000, Erläuterung zu Blatt Nr. 3724 Pattensen (Geological map of Lower Saxony 1:25 000, explanatory notes on sheet 3724 Pattensen). Niedersächsisches Landesamt für Bodenforschung Hannover: $192 \mathrm{pp}$ (in German.

Rohde P, 1989. Elf pleistozäne Sand-Kies-Terrassen der Weser: Erläuterungen eines Gliederungsschemas für das obere Weser-Tal (Eleven Pleistocene Sand and Gravel Terraces of the Weser River: Explanation of a Classification System fort he Upper Weser Valley). E\&G Quaternary Science Journal 39(1): 42-56, DOI 10.3285/eg.39.1.06. (in German)

Rohde P, 1994. Weser und Leine am Berglandrand zur Ober- und Mittelterrassen-Zeit (The Weser and Leine Rivers near the northern edge of the Niedersachsen Upland during Upper Terrace and Middle Terrace periods). E\&G Quaternary Science Journal 44(1): 106-133, DOI 10.3285/eg.44.1.10. (in German)

Rohde P, Lepper J and Thiem W, 2012. Younger Middle Terrace Saalian pre-Drenthe deposits overlying MIS 7 Nachtigall interglacial strata near Höxter/Weser, NW-Germany. E\&G Quaternary Science Journal 61(2): 133-145, DOI 10.3285/eg.61.2.01.

Roskosch J, Winsemann J, Polom U, Brandes C, Tsukamoto S, Weitkamp A, Bartholomäus WA, Henningsen D and Frechen M, 2015. Luminescence dating of ice-marginal deposits in northern Germany: evidence for repeated glaciations during the Middle Pleistocene (MIS 12 to MIS 6). Boreas 44(1): 103-126, DOI 10.1111/bor.12083.

Siegert L, 1912. Über die Entwicklung des Wesertales (About the evolution of the Weser Valley). Zeitschrift der Deutschen Geologischen Gesellschaft 64: 233-264 (in German).

Siegert L, 1921. Beiträge zur Kenntnis des Pliocäns und der diluvialen Terrassen im Flußgebiet der Weser (Notes on the knowledge of the Pliocene and the Diluvian terraces in the area of River Weser). Abhandlungen der Preußischen Geologischen Landesanstalt, Neue Folge 90, Berlin: 130pp (in German).

Soergel W, 1927. Zur Talentwicklung des Weser-Werra- und des Ilm-
Systems (About the valley evolution of the Weser-Werra and Ilm systems). Geologische Rundschau 18: 103-120 (in German).

Soergel W, 1939. Das diluviale System (The Diluvian System). Fortschritte der Geologie und Paläontologie 12: 155-292 (in German).

Spooner NA, 1994. The anomalous fading of infrared-stimulated luminescence from feldspars. Radiation Measurements 23(2-3): 625632, DOI 10.1016/1350-4487(94)90111-2.

Stokes S, Bray HE and Blum MD, 2001. Optical resetting in large drainage basins: Tests of zeroing assumptions using single-aliquot procedures. Quaternary Science Reviews 20(5-9): 879-885, DOI 10.1016/S0277-3791(00)00045-7.

Thiel C, Buylaert J-P, Murray A, Terhorst B, Hofer I, Tsukamoto S and Frechen M, 2011. Luminescence dating of the Stratzing loess profile (Austria) - Testing the potential of an elevated temperature post-IR IRSL protocol. Quaternary International 234(1-2): 23-31, DOI 10.1016/j.quaint.2010.05.018.

Thomas PJ, Murray AS, Kjær KH, Funder S and Larsen E, 2006. Optically Stimulated Luminescence (OSL) dating of glacigenic sediments from Arctic Russia - depositional bleaching and methodological aspects. Boreas 35(3). 587-599, DOI 10.1080/03009480600781933.

Thomsen KJ, Bøtter-Jensen L, Jain M, Denby PM and Murray AS, 2008a. Recent instrumental developments for trapped electron dosimetry. Radiation Measurements 43(2-6): 414-421, DOI 10.1016/j.radmeas.2008.01.003.

Thomsen KJ, Murray AJ, Jain M and Bøtter-Jensen L, 2008b. Laboratory fading rates of various luminescence signals from feldspar-rich sediment extracts. Radiation Measurements 43(9-10): 1474-1486, DOI 10.1016/j.radmeas.2008.06.002.

Tsukamoto S, Denby PM, Murray AS and Bøtter-Jensen L, 2006. Timeresolved luminescence from feldspars: new insight into fading. Radiation Measurements 41(7-8): 790-795, DOI 10.1016/j.radmeas.2006.05.013

Waas D, Kleinmann A and Lepper J, 2011. Uranium-thorium dating of fen peat horizons from pit Nachtigall in northern Germany. Quaternary International 241(1-2): 111-124, DOI 10.1016/j.quaint.2010.09.010.

Wallinga J, 2002. Opically stimulated luminescence dating of fluvial deposits: a review. Boreas 31(4): 303-322, DOI 10.1111/j.15023885.2002.tb01076.x.

Wallinga J, Murray A and Wintle A, 2000. The single-aliquot regenerative-dose (SAR) protocol applied to coarse-grain feldspar. Radiation Measurement 32(5-6): 529-533, DOI 10.1016/S13504487(00)00091-3.

Wallinga J, Murray AS, Duller GAT and Törnqvist TE, 2001. Testing optically stimulated luminescence dating of sand-sized quartz and feldspar from fluvial deposits. Earth and Planetary Science Letters 193(3-4): 617-630, DOI 10.1016/S0012-821X(01)00526-X.

Winsemann J, Lang J, Böhner U, Polom U, Brandes C, Roskosch J, Glotzbach C and Frechen M, 2015. Terrace styles and timing of terrace formation in the Weser and Leine Valley, northern Germany: response of a fluvial system to climate change and glaciation. Quaternary Science Reviews 123: 31-57, DOI 10.1016/j.quascirev.2015.06.005.

Wintle AG, 1973. Anomalous fading of thermoluminescence in minerals. Nature 245: 143-144, DOI 10.1038/245143a0.

Zhao J, Lai Z, Liu S, Song Y, Li Z and Yin X, 2012. OSL and ESR dating of glacial deposits and its implications for glacial landform evolution in the Bogeda Peak area, Tianshan range, China. Quaternary Geochronology 10: 237-243, DOI 10.1016/j.quageo.2012.03.004. 